\title{
Green Synthesis of Zinc Nanoparticles using Pseudomonas fluorescens Extract and Their Antibacterial Activity against Xanthomonas spp.
}

\author{
J.U. Vinay ${ }^{1 *}$, V.B. Nargund ${ }^{1}$, S. Jahagirdhar ${ }^{1}$, R.R. Patil ${ }^{2}$ and R.V. Hegde ${ }^{3}$ \\ ${ }^{1}$ Department of Plant Pathology, ${ }^{2}$ Department of Agricultural Entomology, ${ }^{3}$ Department of \\ Horticulture, College of Agriculture, University of Agricultural Sciences, \\ Dharwad - 580 005, Karnataka, India \\ *Corresponding author
}

\section{A B S T R A C T}

In the field of plant pathology, exploitation of metal nanoparticles in bacterial disease management is a novel and needy approach. Green synthesis of nanoparticles is most prioritized because of their safe, eco-friendly nature and cost effectiveness. A total of 16

\section{Keywords}

Zinc utilization, Zinc nanoparticles,

Pseudomonas

fluorescens, Antibacterial activity, Xanthomonas spp.

\section{Article Info}

Accepted:

10 September 2018 Available Online: 10 October 2018 fluorescent pseudomonad isolates were obtained from different crop rhizosphere in various locations. The isolates were screened for zinc utilization capabilities. Among the 16 isolates, one isolate (FPGrChHi-6) showed maximum zone of zinc utilization $(30.00 \mathrm{~mm})$ with bacterial growth $(12.00 \mathrm{~mm})$. Molecular characterization of isolate revealed that, isolate FPGrChHi-6 belongs to Pseudomonas fluorescens. Further, zinc nanoparticles (ZnNPs) were synthesized by using $P$. fluorescens extract. The green synthesized ZnNPs were characterized using various instruments. The UV-vis spectrophotometer analysis showed the prominent peak at $360 \mathrm{~nm}$, which indicated the synthesis of ZnNPs. The characterization through particle size analyzer and atomic force microscope found that, the mean diameter of ZnNPs was found to be $21.40 \mathrm{~nm}$ with spherical to irregular in shape. ZnNPs showed phytotoxicity symptoms on tomato seedlings at $1500 \mathrm{ppm}$ concentration and onwards. ZnNPs showed excellent antibacterial activity against Xanthomonas oryzae pv. oryzae and Xanthomonas axonopodis pv. punicae. Among tested concentrations, maximum inhibition zones were noticed against Xap $(21.76 \mathrm{~mm})$ and Xoo $(15.67 \mathrm{~mm})$ at $1000 \mathrm{ppm}$ and $1250 \mathrm{ppm}$ concentrations respectively.

\section{Introduction}

Nanotechnology is emerging as a revolutionary technology in the current era. It deals with the matter considered at nanoscale $(1-100 \mathrm{~nm})$ and their implication for the welfare of human beings. Materials reduced to the nanoscale show some unusual properties which are different from what they exhibit on a macro scale, enabling unique systematic applications. Nanoparticles produced by a biogenic enzymatic process are far superior, in several ways, to those particles produced by chemical methods. Currently, there is a 
growing need in using environmentally friendly nanoparticles that do not produce toxic wastes in their synthesis process. It is well known that biological entities like microorganisms and living cells are the best examples of machines that possess operating parts at the nano-scale level and perform a number of bio-chemical reactions ranging from generation of energy to extraction of targeted materials at a very high efficiency (Goodsell, 2004).

Bacterial blight of pomegranate (Punica granatum L.) caused by Xanthomonas axonopodis pv. punicae in recent years has become one of the most serious diseases in India. Under epidemic conditions blight resulted in yield losses up to 80 per cent (Benagi et al., 2012, Sharma et al., 2015). Similarly, bacterial leaf blight (Xanthomonas oryzae pv. oryzae) is major thereat for the rice production in India. The disease in its severe form is known to results in yield loss ranges from 74-81 per cent in susceptible cultivar (Shivalingaiah et al., 2013).

Presently, plant protection sectors ruling by only few antibiotics for management of bacterial plant diseases. Some of the bacterial pathogens are acquiring antibiotic resistance nature in recent days. Novel molecule is much needed to overcome these problems. Hence, zinc nanoparticles introduced in the field of plant pathology. Zinc oxide nanoparticles have been extensively used in agricultural and industrial sectors. $\mathrm{ZnO}$ is nontoxic and it is a strong antibacterial agent. $\mathrm{ZnO}$ nanoparticles have bactericidal effects on both grampositive and gram-negative bacteria (Arabi et al., 2012).

Considering the experimental evidence and emergence of nanotechnology in agriculture, an effort was made to expand in the field of plant pathology to manage plant diseases, bacterial blight of pomegranate and rice through synthesis and exploitation of antibacterial nature of zinc nanoparticles.

\section{Materials and Methods}

\section{Collection, isolation and characterization of fluorescent Pseudomonas isolates from different crops rhizosphere and locations}

Soil samples were collected from the 16 crop rhizosphere of 13 locations (Table 1). The healthy plants in the vicinity of sick plants were collected by uprooting the plants, 80-100 $\mathrm{g}$ of rhizosphere soil was collected for isolation of fluorescent pseudomonads.

Isolation of fluorescent Pseudomonas was carried out by serial dilution technique. $10 \mathrm{~g}$ rhizosphere soil was transferred to $100 \mathrm{ml}$ of sterile water blank then one $\mathrm{ml}$ of this suspension was made into serial dilution up to $10^{-5}, 10^{-6}$ and $0.1 \mathrm{ml}$ of this was placed on King's B medium to isolate the colonies. Plates were incubated at $28{ }^{\circ} \mathrm{C}$ for $48 \mathrm{hr}$. The individual colonies which showed bluish green fluorescent emission were selected and sub cultured. All the isolates were maintained on King's B medium.

All the isolates of fluorescent Pseudomonas were tested for growth assay at $4{ }^{\circ} \mathrm{C}$ and $42{ }^{\circ} \mathrm{C}$ temperature to differentiate between Pseudomonas aeruginosa and P. fluorescens (King and Phillips, 1978). The cultures were streaked on King's B medium and incubated at $4{ }^{\circ} \mathrm{C}$ and $42{ }^{\circ} \mathrm{C}$ temperature for $48 \mathrm{hr}$. Further growth of cultures was observed.

\section{Coding of fluorescent pseudomonad isolates}

The isolates were coded by using eight letters. First two letters indicated organism's name (Fluorescent Pseudomonad), third and fourth letters indicated the host rhizosphere (BaBanana, Ca-Castor, Ch-Chilli), fifth and sixth letters indicated the district from which 
organism was isolated (Ch-Chitradurga, DhDharwad) and last two letters indicated the village/location name (Ja- Jayasuvarnapura, Ha-Harihara).

\section{Screening of fluorescent pseudomonad} isolates for zinc utilization

Zinc dominated minimal media was prepared $\left(\mathrm{KH}_{2} \mathrm{PO}_{4} \quad 2.5 \mathrm{~g} / 1, \quad \mathrm{NaCl} 2.5 \mathrm{~g} / 1\right.$, Glycerol 10 $\mathrm{ml} / \mathrm{l}, \mathrm{ZnO} 2.5 \mathrm{~g} / \mathrm{l}$, Agar $20 \mathrm{~g} / \mathrm{L}$, Distilled water $11)$. The fluorescent pseudomonas cultures of different isolates were spotted on solidified media in Petri plates separately. The plates were incubated at $28{ }^{0} \mathrm{C}$ for 4 days. Further zone of zinc utilization was measured around the culture spotted area. The superior isolate having maximum zone of utilization was selected for synthesis of zinc nanoparticles.

\section{Molecular characterization of efficient fluorescent pseudomonad isolate}

The DNA of efficient fluorescent Pseudomonas isolate (FPGrChHi-6) was extracted by using HiMedia bacterial genomic DNA extraction kit. Amplification of $16 \mathrm{~S}$ rRNA gene from the genomic DNA of bacteria was done by using universal primer set, fD1 and rP2 primers (Liu et al., 2006).

\section{Synthesis of Pf-ZnNPs}

$P$. fluorescens culture was allowed to grow as culture suspension in nutrient broth to attain the full growth (48 h). After incubation period, the culture was centrifuged $(5,000 \mathrm{x} \mathrm{g})$ for 30 min and supernatant was used for the biosynthesis of ZnNPs.

The synthesis protocol was modified from Getie et al., 2017. Briefly, in $80 \mathrm{ml}$ of hot distilled water, $125 \mathrm{mg}$ of $\mathrm{ZnO}$ was dissolved and kept on magnetic stirring for $10 \mathrm{~min}$. Pfextract $(10 \mathrm{ml})$ was added drop wise to $\mathrm{ZnO}$ solution under magnetic stirring condition. 1 $\mathrm{ml}$ of glycerol was added to the mixture followed by addition of $10 \mathrm{ml}$ of Pf- extract and continued magnetic stirring for $24 \mathrm{~h}$. Further, microwave irradiation treatment was done for $1 \mathrm{~min}$ at $800 \mathrm{~W}$ followed by ultrasonication for $30 \mathrm{~min}$.

\section{Characterization of Pf-ZnNPs}

Synthesized nanoparticles were characterized to know the shape, size and other parameters using UV-Visible Spectrophotometer, Particle Size Analyser (PSA) and Atomic Force Microscope (AFM). For characterization under UV-Visible Spectrophotometer and PSA, $10 \mathrm{mg}$ of Pf-ZnNPs was suspended in $100 \mathrm{ml}$ of sterile distilled water and sonicated for $20 \mathrm{~min}$ for uniform distribution of nanoparticles. Then $3 \mathrm{ml}$ of sonicated PfZnNPs were subjected for PSA analysis (Nicomp, USA). Similarly size and shape of the nanoparticles were determined by using Atomic Force Microscope (Nanosurf AG, Swiss, Flex AFM, with 24bit C3000). For AFM characterization sonicated sample was coated on mica sheet and kept for overnight under hot air oven at $45{ }^{0} \mathrm{C}$ then characterized by AFM in dynamic mode by using NCLR-10 cantilever.

\section{Determination of phytotoxicity range of ZnNPs on tomato seedlings}

The characterized ZnNPs were tested to know their phytotoxicity range on tomato seedlings from 1 to 2,000 ppm concentrations under glasshouse conditions with corresponding checks. Tomato seedlings of Arka Vikas variety raised in coco peat tray for twenty days were transferred to small pots filled with sterilized soil and allowed for few days for better establishment. Later phytotoxicity of green synthesized ZnNPs were tested at 1 to 2,000 ppm on 30 days old tomato seedlings of by spraying method under glasshouse condition. Observations were recorded on 1, 3, 
5 and 7 days after spraying for expression of various symptoms of phytotoxicity (hyponasty, epinasty, vein clearing, stunting, scorching, necrosis and chlorosis).

Isolation and characterization of Xanthomonas oryzae pv. oryzae and Xanthomonas axonopodis pv. punicae.

Diseased specimens were collected from rice and pomegranate plants. Infected tissue showed typical characteristic symptoms and isolated by standard procedures by using nutrient agar medium. Pure virulent cultures of Xanthomonas oryzae pv. oryzae (Xoo) and Xanthomonas axonopodis pv. punicae (Xap) were isolated from the plants were maintained on nutrient agar medium at $4{ }^{\circ} \mathrm{C} . X . \quad o$. pv. oryzae and $X . a$. pv. punicae were tested on rice (BPT-5204) and pomegranate (Bhagwa) respectively for pathogenicity under glass house conditions.

The DNA of both plant pathogenic bacteria was extracted by using HiMedia bacterial genomic DNA extraction kit. Amplification of 16S rRNA gene from the genomic DNA of bacteria was done by using universal primer set, fD1 and rP2 primers. Amplified products were checked on 1.4 per cent agarose gel.

The amplified products were sent for sequencing to know the nucleotide sequence and further the sequences were analyzed in NCBI BLAST software to confirm the species name of the isolated organism.

\section{Evaluation of Pf-ZnNPs against} Xanthomonas spp.

Characterized nanoparticles were evaluated under in vitro against Xanthomonas spp. by standard paper disc method at different concentrations (10-1250 ppm). Loop full of (72 $\mathrm{h}$ old) of $X$. axonopodis pv. punicae and Xanthomonas oryzae pv. oryzae were multiplied on nutrient broth. Pathogenic suspension of $300 \mu \mathrm{l}$ was spread on nutrient glucose agar, sterilizing filter paper discs (Whatman No. 1) measuring $5 \mathrm{~mm}$ diameter were soaked for $10 \mathrm{~min}$ in different concentrations of ZnNPs. Dipped discs placed on the surface of media seeded with bacterial cultures separately. The sterilized filter paper discs were dipped in sterilized water/antibiotics/microbial extract/bulk $\mathrm{ZnO}$ served as control checks. The inoculated plates were incubated at $26 \pm 2{ }^{\circ} \mathrm{C}$. Four replications were maintained for each treatment. Observation was recorded by measuring the diameter of the inhibition zone around the filter paper disc.

\section{Results and Discussion}

The development of noble eco-friendly nanoscaled particles is a challenge as these are safe and eco-friendly in their synthetic processes. The microbes produce several hydrolytic enzymes and pigments which play an important role in reduction of metal ions. Zinc oxide exhibits antibacterial activity that increases with decreasing particle size. Nanoparticle synthesis is an important component of rapidly growing research efforts in nanoscale science and engineering (Bansal et al., 2004).

\section{Collection, isolation and characterization of fluorescent Pseudomonas isolates}

Sixteen fluorescent Pseudomonas isolates were collected from the rhizosphere soil of 16 crops (Table 1). All the isolates showed Gramnegative reaction, rod shaped and pigment production was seen in King's B medium under UV light (Fig. 1). In growth assay study, all the isolates were grown at $4 \square \mathrm{C}$ but not showed any growth at $42{ }^{\circ} \mathrm{C}$. The results revealed that, all isolates were not belonged to Pseudomonas aeruginosa group. The similar results were observed by (Singh et al., 2015). 
Screening of fluorescent Pseudomonas isolates for zinc utilization on zinc dominated minimal media revealed that, among tested 16 isolates FPGrChHi-6 isolate was found to be superior in zinc utilization $(30.00 \mathrm{~mm}$ zone of utilization and $12.00 \mathrm{~mm}$ of bacterial growth) followed by FPCoHaRa-3 isolate $(20.00 \mathrm{~mm}$ zone of utilization and $9.50 \mathrm{~mm}$ of bacterial growth) compared to other isolates (Table 2).

Four isolates (FPPiKaKv-11, FPPoChJa-12, FPSuDhAc-15 and FPToBeNi-16) lacked zinc utilization capacity (Fig. 2).

The results are in agreement with Anuradha and Syed, (2016) who identified the variation in zinc utilization. Hence, FPGrChHi-6 isolate was selected for molecular characterization.

Further identification of species of fluorescent pseudomonad isolate through 16S rRNA sequence analysis revealed that, the isolate FPGrChHi-6 belonged to Pseudomonas fluorescens.

The results were similar with Trivedi et al., (2015). The FPGrChHi-6 was isolated from groundnut rhizosphere of Hiriyur taluka and Chitradurga district. Further, this isolate was selected for synthesis of zinc nanoparticles.

\section{Synthesis and characterization of Pf-ZnNPs}

The eco-friendly synthesis of zinc nanoparticles was challenged and needed effort for successful exploitation of nanoparticles in the field of plant pathology. The integration of nanotechnology in management of plant disease management solves the many risks in the area of plant protection. Exploitation of green synthesized nanoparticles is required for combating of bacterial diseases of plants.

Zinc nanoparticles were successfully synthesized using extract of Pseudomonas fluorescens with magnetic stirring and microwave treatments. The white uniformly dispersion of reaction mixture $(\mathrm{ZnO}+\mathrm{Pf}-$ extract) indicated the successful synthesis of zinc nanoparticles. Similar observation was recorded by Getie et al., (2017). The extracelluar enzymes, volatiles and oxidative compounds released from microbes acts best reducing agents of metal compounds in to nanoparticles.

The other secondary metabolites like proteins also serve as capping agents for nanoparticles (Kundu et al., 2014). Extracellular secretion of enzymes offers the advantage to obtain pure, monodisperse nanoparticles, Some microorganisms can survive and grow even at higher metal ion concentration due to their resistance to the metal.

The mechanisms involve: efflux systems, alteration of solubility and toxicity via reduction or oxidation, biosorption, bioaccumulation, extra cellular complexation or precipitation of metals results in nanoscale reduction (Husseiny et al., 2007); Harish kumar and Savalgi (2016).

Characterization of synthesized nanoparticles was done using UV- vis spectrophotometer, particle size analyzer and atomic force microscope. The promising peak at $370 \mathrm{~nm}$ in UV- vis spectrophotometer analysis initially confirmed synthesis of zinc nanoparticles (Fig. 3). Similar peak was noticed by Malaikozhundan et al., 2017, wherein they reported that, absorption peak at $373 \mathrm{~nm}$ was characteristic of ZnONPs. The particle size analyzer results revealed that, zinc nanoparticles has mean diameter of $21.40 \mathrm{~nm}$ with uniform size distribution (Fig. 4). The atomic force microscope analysis revealed that, nanoparticles were spherical to irregular in shape (Fig. 5). Similar results were observed by Nagarajan and Kuppusamy (2013); Harish kumar and Savalgi, (2016). 
Table.1 Coding of fluorescent pseudomonad isolates collected from different crops rhizosphere

\begin{tabular}{|c|c|c|c|c|c|}
\hline \multirow{2}{*}{$\begin{array}{l}\text { Sl. } \\
\text { No }\end{array}$} & \multirow{2}{*}{$\begin{array}{c}\text { Crop } \\
\text { (Rhizosphere) }\end{array}$} & \multirow[t]{2}{*}{ District } & \multirow[t]{2}{*}{ Taluk } & \multirow[t]{2}{*}{ Location/Village } & Isolate code for \\
\hline & & & & & $\begin{array}{c}\text { Fluorescent } \\
\text { Pseudomonas }\end{array}$ \\
\hline 1 & Banana & Chitradurga & Hosadurga & Jayasuvarnapura & FPBaChJa-1 \\
\hline 2 & Chilli & Davanagere & Harihara & Harihara & FPChDaHa-2 \\
\hline 3 & Cotton & Haveri & Ranebennur & Ranebennur & FPCoHaRa-3 \\
\hline 4 & Fingermillet & Tumkur & Chikkanayakanahalli & Kenkere & FPFiTuKe-4 \\
\hline 5 & Ginger & Uttarkannada & Sirsi & Sirsi & FPGiUtSi-5 \\
\hline 6 & Groundgnut & Chitradurga & Hiriyur & Hiriyur & FPGrChHi-6 \\
\hline 7 & Maize & Dharwad & Dharwad & UAS campus & FPMaDhAc-7 \\
\hline 8 & Niger & Chitradurga & Molakalmur & Molakalmur & FPNiChMo-8 \\
\hline 9 & Onion & Kolar & Malur & Malur & FPOnKoMa-9 \\
\hline 10 & Paddy & Koppal & Ganagavathi & Ganagavathi & FPPaKoGa-10 \\
\hline 11 & Pigeon pea & Kalaburgi & Kalaburgi & KVK & FPPiKaKv-11 \\
\hline 12 & Pomegranate & Chitradurga & Hosadurga & Jayasuvarnapura & FPPoChJa-12 \\
\hline 13 & Sesamum & Raichur & Manvi & Kallur & FPSeRaKa-13 \\
\hline 14 & Soyabean & Dharwad & Dharwad & UAS campus & FPSoDhAc-14 \\
\hline 15 & Sunflower & Dharwad & Dharwad & UAS campus & FPSuDhAc-15 \\
\hline 16 & Tobacco & Belagavi & Nippani & Nippani & FPToBeNi-16 \\
\hline
\end{tabular}

Table.2 Zinc utilization by fluorescent pseudomonad isolates

\begin{tabular}{|c|c|}
\hline Isolates \\
\hline FPBaChJa-1 \\
\hline FPChDaHa-2 \\
\hline FPCoHaRa-3 \\
\hline FPFiTuKe-4 \\
\hline FPGiUtSi-5 \\
\hline FPGrChHi-6 \\
\hline FPMaDhAc-7 \\
\hline FPNiChMo-8 \\
\hline FPOnKoMa-9 \\
\hline FPPaKoGa-10 \\
\hline FPPiKaKv-11 \\
\hline FPPoChJa-12 \\
\hline FPSeRaKa-13 \\
\hline FPSoDhAc-14 \\
\hline FPSuDhAc-15 \\
\hline FPToBeNi-16 \\
\hline FPIOFDh \\
\hline S.Em. \\
\hline C.D. @ $1 \%$ \\
\hline * Transformed value $\sqrt{\boldsymbol{x}+1}$
\end{tabular}

\begin{tabular}{|c|c|}
\hline Zone of utilization $(\mathbf{m m})$ & Bacterial growth $(\mathbf{m m})$ \\
\hline $13.00(3.74)^{*}$ & $11.00(3.46)$ \\
\hline $16.00(4.12)$ & $10.50(3.39)$ \\
\hline $20.00(4.58)$ & $9.50(3.24)$ \\
\hline $15.00(4.00)$ & $9.50(3.24)$ \\
\hline $11.00(3.46)$ & $9.50(3.24)$ \\
\hline $30.00(5.57)$ & $12.00(3.61)$ \\
\hline $12.00(3.61)$ & $9.50(3.24)$ \\
\hline $11.00(3.46)$ & $9.50(3.24)$ \\
\hline $15.00(4.00)$ & $10.50(3.39)$ \\
\hline $15.00(4.00)$ & $12.50(3.67)$ \\
\hline $0.00(1.00)$ & $12.00(3.61)$ \\
\hline $0.00(1.00)$ & $12.00(3.61)$ \\
\hline $16.00(4.12)$ & $11.50(3.54)$ \\
\hline $18.00(4.36)$ & $11.00(3.46)$ \\
\hline $0.00(1.00)$ & $12.00(3.61)$ \\
\hline $0.00(1.00)$ & $11.50(3.54)$ \\
\hline $0.00(1.00)$ & $12.00(3.61)$ \\
\hline 0.03 & 0.02 \\
\hline 0.13 & 0.09 \\
\hline
\end{tabular}


Table.3 In vitro efficacy of Pseudomonas fluorescens based Zinc nanoparticles (Pf-ZnNPs) against Xanthomonas spp.

\begin{tabular}{|c|c|c|c|}
\hline \multirow{2}{*}{ Treatments } & $\begin{array}{c}\text { Concentration } \\
(\mathrm{ppm})\end{array}$ & \multicolumn{2}{|c|}{ Zone of inhibition (mm) } \\
\hline & 10 & Xap & Xoo \\
\hline Pf- ZnNPs & 25 & $3.00(2.00)^{*}$ & $0.00(1.00)$ \\
\hline & 50 & $11.00(3.46)$ & $0.00(1.00)$ \\
\hline & 100 & $13.33(3.79)$ & $8.33(3.06)$ \\
\hline & 250 & $19.33(4.51)$ & $10.00(3.32)$ \\
\hline P. fluorescens & 500 & $20.33(4.62)$ & $11.67(3.56)$ \\
\hline extract & 1000 & $21.67(4.76)$ & $13.67(3.83)$ \\
\hline Bulk ZnO & 1250 & $21.67(4.76)$ & $14.67(3.96)$ \\
\hline Streptocyclin & 1250 & $0.00(1.00)$ & $15.67(4.08)$ \\
\hline Water control & 500 & $0.00(1.00)$ & $0.00(1.00)$ \\
\hline S. Em. \pm & - & $25.33(5.13)$ & $0.00(1.00)$ \\
\hline C.D. @ 1\% & & $0.00(1.00)$ & $19.67(4.55)$ \\
\hline
\end{tabular}

* Transformed value $\sqrt{x+1}$

Fig.1 Fluorescence emission by $P$. fluorescens (FPGrChHi-6) under UV-light (254 nm)

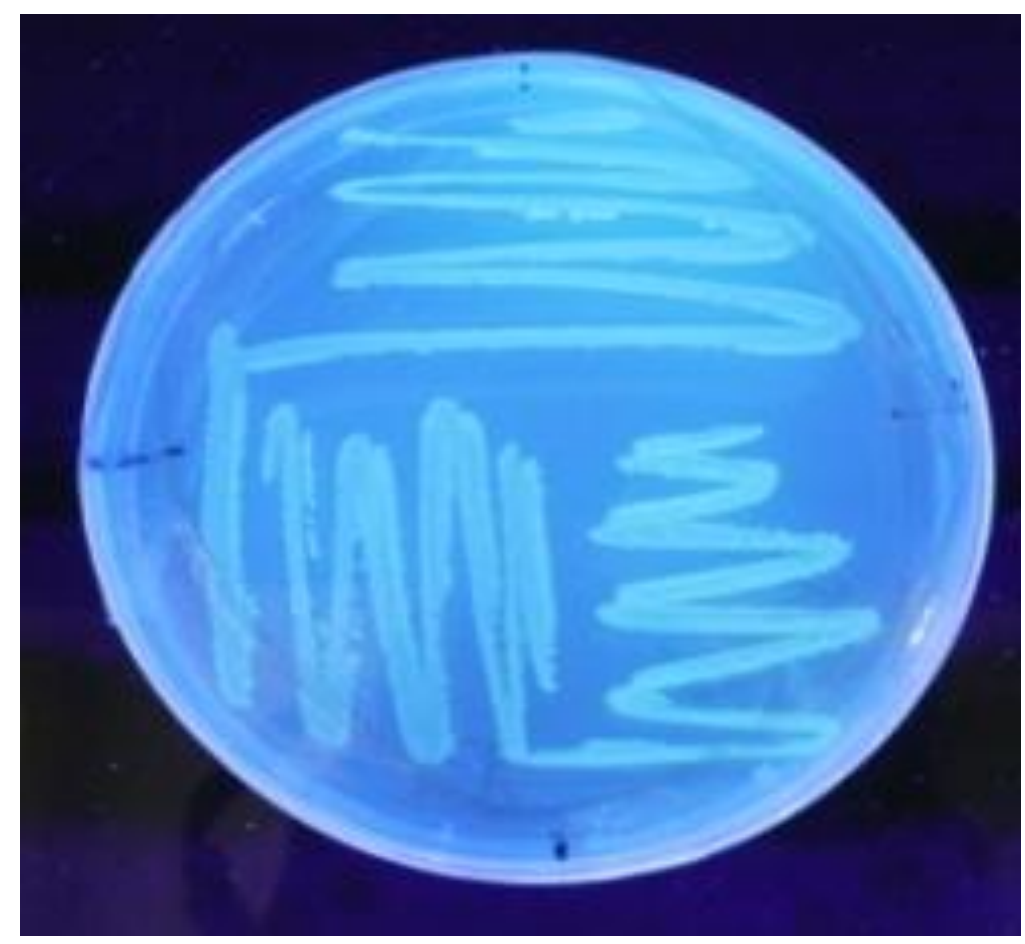


Fig.2 Zinc utilization by fluorescent pseudomonad isolates

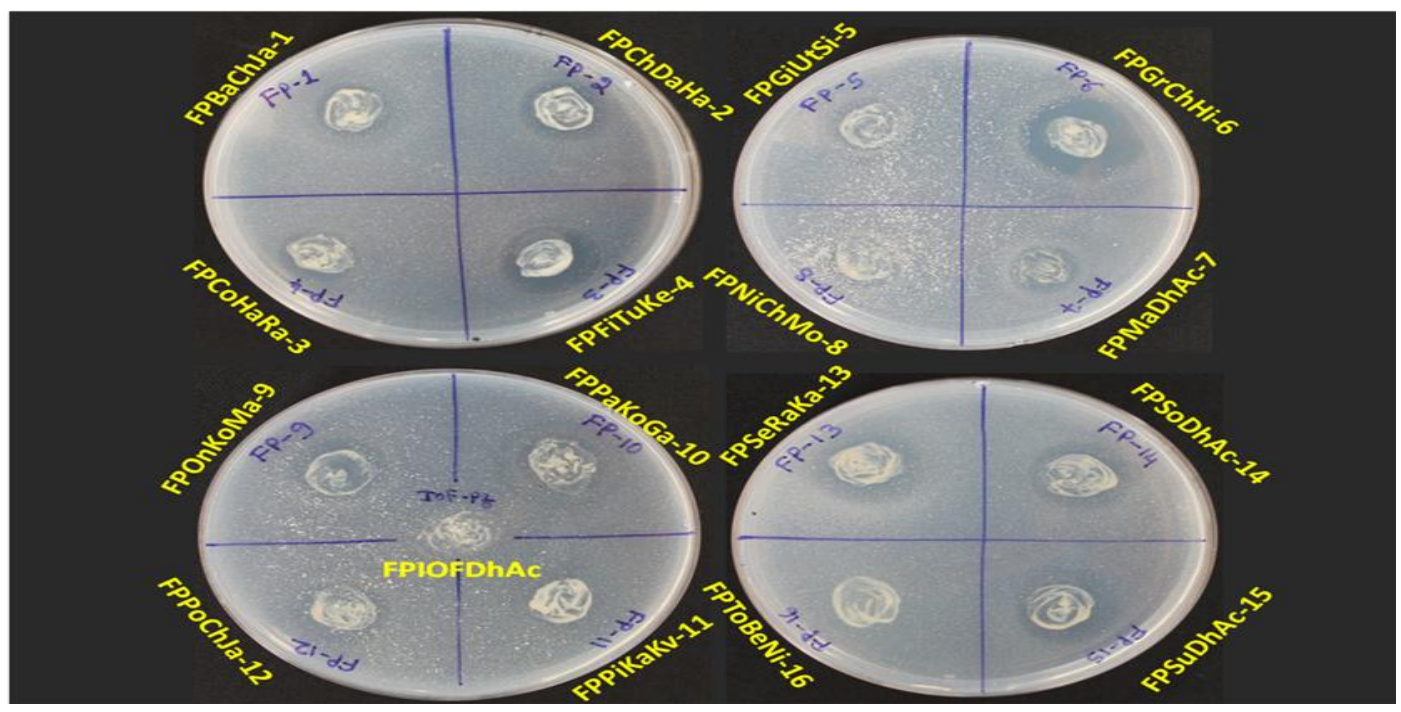

Fig.3 UV-Visible spectral graph of Pf-ZnNPs (Peak at $370 \mathrm{~nm}$ )

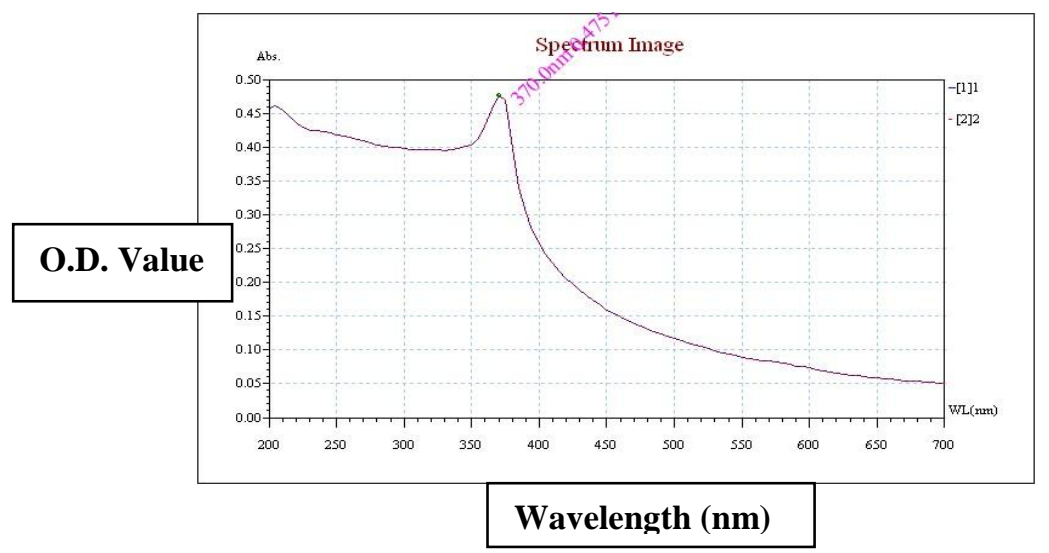

Fig.4 Characterization of Pf-ZnNPs under particle size analyzer $(21.40 \mathrm{~nm})$

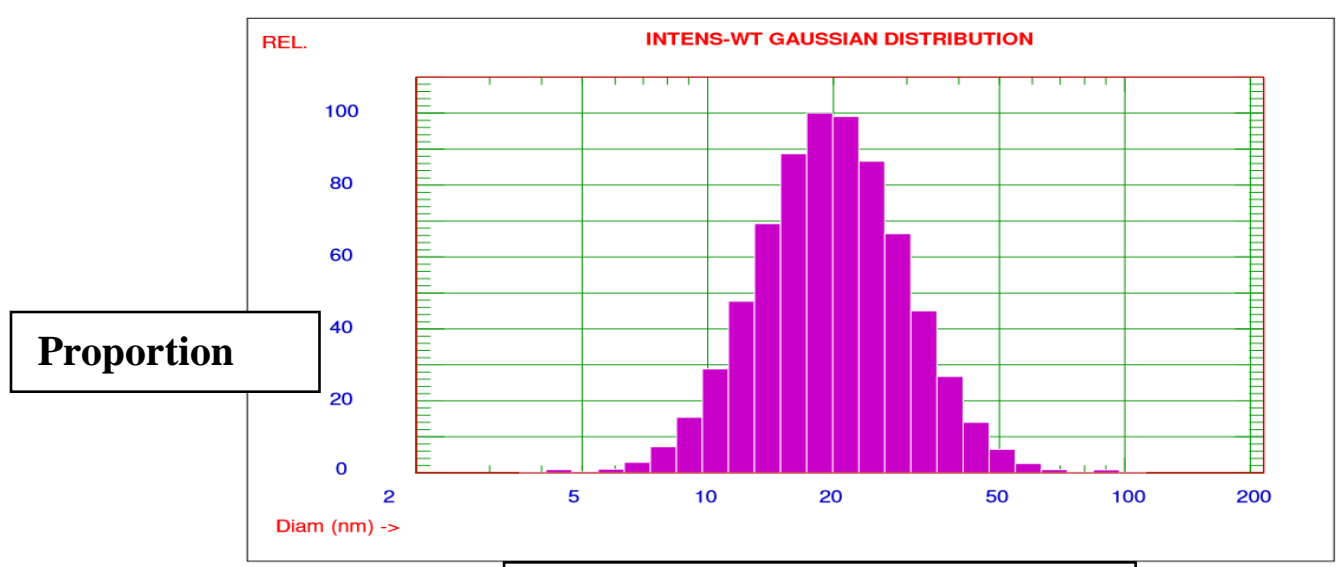

Diameter of nanoparticles (nm) 
Fig.5 Characterization of Pf-ZnNPs under atomic force microscope

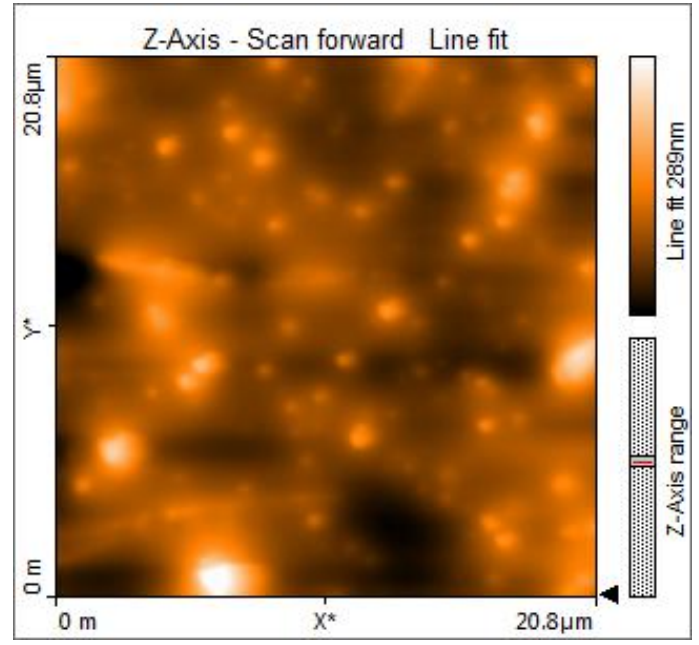

Fig.6 In vitro efficacy of Pf-ZnNPs against Xanthomonas spp.

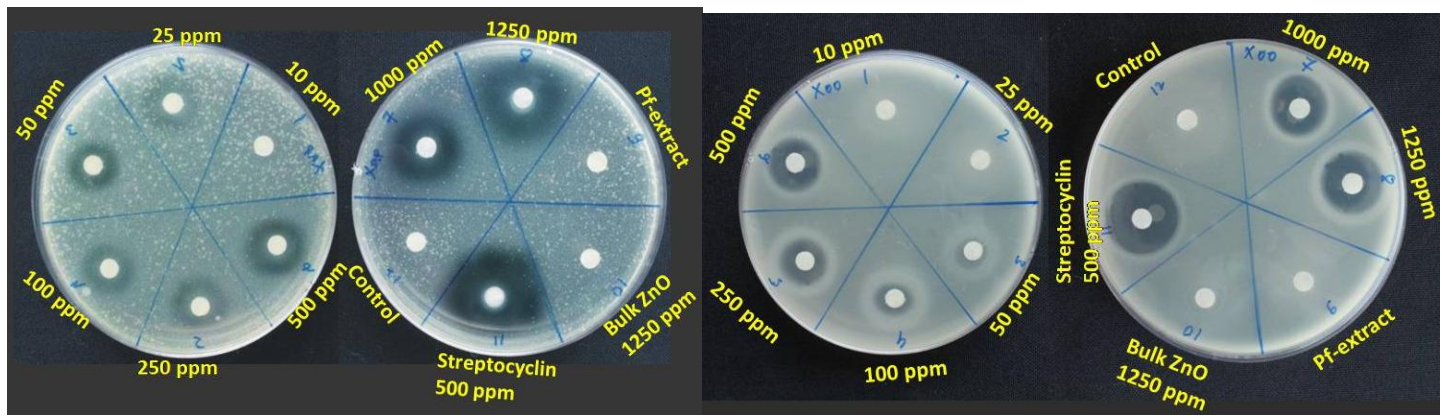

Xanthomonas axonopodis pv. punicae

Xanthomonas oryzae pv. oryzae

The phytotoxicity studies of Pf-ZnNPs on tomato revealed that, the toxicity symptoms were observed on tomato leaves at above $1500 \mathrm{ppm}$ concentration with characteristic necrotic lesion and leaf drooping symptoms on seven days after inoculation.

The concentration from $1-1250 \mathrm{ppm}$ were safest concentrations for foliar application on plants against diseases. Hence, concentrations upto $1250 \mathrm{ppm}$ were used for evaluation against pathogens.

The present results are in agreement with Prakash and Ching (2016), wherein they reported the phytotoxicity of ZnONPs on wheat seedlings at higher concentration $(>400$ $\mathrm{mg} / \mathrm{L}$ ).

Characterization of Xanthomonas spp. of rice and pomegranate

Colonies of $X$. o. pv. oryzae formed on nutrient agar were creamy-yellow with copious slime, raised and convex. Colonies of $X$. a. pv. punicae were pale yellow to dark yellow and later turned to metallic yellow colour. These pure cultures of pathogens were used for proving pathogenicity. After glasshouse inoculation, typical symptoms of bacterial blight of pomegranate i.e., water soaked lesions with yellow hallow developed 
on the surface leaves. In rice, inoculated plants showed characteristic symptom of bacterial blight i.e., water-soaked streaks that spread from the leaf tips and margins. These characteristic symptoms confirmed the virulent nature of pathogens. The similar observations were made previously by Shankara et al., (2017) and Giri et al., (2011).

The pathogens were further confirmed at molecular level by using 16s rRNA analysis. The amplified products has $1500 \mathrm{bp}$ in length and sequencing followed by BLAST analysis of these amplicons confirmed the pathogens of pomegranate and rice as $X$. axonopodis pv. punicae and Xanthomonas oryzae pv. oryzae respectively. The similar results were observed by Mondal et al., (2012): Shivalingaiah et al., (2012). These pathogenic cultures were further used for in vitro experiments.

\section{Evaluation of Pf-ZnNPs against Xanthomonas spp.}

Zinc nanoparticles are known to possess antibacterial activity. When the particle size of zinc oxide decreased, antibacterial activity increased. Further, characters of nanoparticles also changed (Bansal et al., 2004). Hence, by exploiting this property of ZnNPs, experimentation was done to suppress the growth of the plant pathogenic bacteria. The synthesized ZnNPs were evaluated against Xanthomonas oryzae pv. oryzae (Xoo) (bacterial blight of rice) and Xanthomonas axonopodis pv. punicae (Xap) (bacterial blight of pomegranate) under in vitro condition. Among the tested concentrations of Pf-ZnNPs, maximum growth inhibition of bacterium was noticed against Xap (21.76.mm) at $1000 \mathrm{ppm}$ and Xoo $(15.76 \mathrm{~mm})$ at $1250 \mathrm{ppm}$ (Fig. 6). The bulk $\mathrm{ZnO}$ (1250 ppm) and Pf-extract (2000000 ppm) did not possess any antibacterial effect on both bacteria (Table 3 ).
The antibiotic Streptocyclin showed maximum zone of inhibition $(19.67 \mathrm{~mm}$ for $X o o$ and $25.33 \mathrm{~mm}$ for Xap) at $500 \mathrm{ppm}$ concentration (Table 3 ). The results are in accordance with Poovizhi and Krishnaveni, (2015) where, they also reported the antibacterial activity of zinc oxide nanoparticles against Escherichia coli, Klebsiella pneumonia and Staphylococcus aureus.

Zinc oxide nanoparticles are antibacterial and inhibit the growth of microorganisms by permeating into the cell membrane. The oxidative stress damages lipids, carbohydrates, proteins, and DNA (Kelly et al., 1998). The antibacterial activity of $\mathrm{ZnO}$ nanoparticles is due in part to their electrostatic interaction with cell surfaces which shows that on contact with bacteria, the cytotoxic actions of $\mathrm{ZnO}$ nanoparticles ruptures the lipid bilayer of bacterium, resulting in leakage of the cytoplasmic substances (Singh et al., 2012).

The zinc utilization capacity of Pseudomonas fluorescens was exploited for successful synthesis of zinc nanoparticles. The ZnNPs were toxic to the tomato seedlings at higher concentration $(>1500 \mathrm{ppm})$. The best concentrations for evaluation against pathogen were determined (1-1250 ppm). Green (microbial) synthesized ZnNPs were successfully inhibited the growth of both bacterial plant pathogens (Xap and Xac). In vitro efficiency of ZnNPs suggests that, integration of ZnNPs in management of bacterial diseases may be considered as best alternative to antibiotics in managing the bacterial plant diseases.

\section{References}

Anuradha, P. and Syed, I., 2016. Evaluation of zinc solubilisation capacity of different microbial strains and their 
effect on bt cotton. Int. J. Agric. Sci. 8(24): 67-75.

Arabi, F., Imandar, M., Negahdary, M., Imandar, M., Noughabi, M. T. and Akbari-dastjerdi, $\quad$ H., 2012. Investigation anti-bacterial effect of zinc oxide nanoparticles upon life of Listeria monocytogenes. Ann. Biol. Res. 3:79-85.

Bansal, V., Rautaray, D., Ahmad, A. and Sastry, M., 2004. Biosynthesis of zirconia nanoparticles using the fungus Fusarium oxysporum. J. Materials Chem. 14(22): 3303-3305.

Benagi, V. I., Ravikumar, M. R. and Nargund, V. B., 2012. Threat of bacterial blight on pomegranate in India - Mitigation by an integrated approach. II Int. Symp. on Pomegranate. pp. 113-116.

Getie, S., Abebe Belay, Chandra reddy, A. R. and Belay, Z., 2017. Synthesis and characterizations of zinc oxide nanoparticles for antibacterial applications. J. Nanomedic. Nanotechnol. 8: 4-12.

Giri, M. S., Prasanthi, S. K., Kulkarni, S., Benagi, V. I. and Hedge, Y. R., 2011. Biochemical and molecular variability among Xanthomonas axonopodis pv. punicae strains, the pathogen of pomegranate bacterial blight. Indian Phytopath. 64 (1): 2-6.

Goodsell, D., 2004. Bionanotechnology: Lessons from nature, Willey- Less, New Jersey, N. J., USA.

Harish kumar, K. and Savalgi, V. P., 2017. Microbial synthesis of zinc nanoparticles using fungus isolated from rhizosphere soil. Int. J. Curr. Microbiol. App. Sci. 6(12): 2359-2364.

Husseiny, M.I., El-Azia, M. A., Badr, Y. and Mahmoud, M. A., 2007. Biosynthesis of gold nanoparticles using Pseudomonas aeruginosa. Spectrochim. Acta, 67:1003-1006.
Kelly, S. A., Havrilla, C. M., Brady, T. C., Abramo, K. H. and Levin, E. D., 1998. Oxidative stress in toxicology: Established mammalian and emerging piscine model systems. Environ. Health Perspect. 106:375-384.

King, A. and Phillips, I., 1978. The identification of pseudomonads and related bacteria in a clinical laboratory. J. Med. Microbiol. 11: 165-176.

Kundu, D., Hazra, C., Chatterjee, A., Chaudhari, A. and Mishra, S., 2014. Extracellular biosynthesis of zinc oxide nanoparticles using Rhodococcus pyridinivorans NT2: Multifunctional textile finishing, biosafety evaluation and in vitro drug delivery in colon carcinoma. J. Photochem. Photobiol. 140: 194-204.

Malaikozhundan, B., Vaseeharana, B., Vijayakumara, S., Merlin, P. and Thangaraj, 2017. Bacillus thuringiensis coated zinc oxide nanoparticle and its biopesticidal eff ects on the pulse beetle, Callosobruchus maculates. J. Photochem. Photobiol. 174: 306-314.

Mondal, K. K., Verma, G. and Mani, C., 2012, Phylogenetic relatedness of Xanthomonas axonopodis pv. punicae, the causal agent of bacterial blight of pomegranate based on two loci, $16 \mathrm{~S}$ rRNA and gyrB. Ann. Microbiol. 9(3): 67-78.

Nagarajan, S. and Kuppusamy, K, A., 2013. Extracellular synthesis of zinc oxide nanoparticle using seaweeds of gulf of Mannar, India. J. Nanobiotechnol. $11: 39$

Poovizhi, J. and Krishnaveni, B., 2015. Synthesis, characterization and antimicrobial activity of zinc oxide nanoparticles synthesized from Calotropis procera. Int. J. Pharma. Sci. and Drug Res. 7(5): 425-431.

Prakash, M. G. and Chung, I. M., 2016. Determination of zinc oxide 
nanoparticles toxicity in root growth in wheat (Triticum aestivum 1.) seedlings. Acta Biologica Hungarica. 67(3): 286296.

Shankara, K., Patil, M. B., Pramesh, D., Sunkad, G., Yenjerappa, S. T., Ibrahim, M., Rajesh, N. L. and Chikkannaswamy, 2017. Characterization of Xanthomonas oryzae pv. oryzae isolates from rice growing regions of southern India. Int. J. Pure App. Biosci. 5 (4): 452-461.

Shivalingaiah and Umesha, S. and Sateesh, M. K., 2012. Detection of Xanthomonas oryzae pv. oryzae in rice seeds by molecular techniques. The Asian and Australasian J. Pl. Sci. and Biotechnol. 6 (1): 44-47.

Shivalingaiah, S., Umesh, A. and Sateesh, M. K., 2013, Cocculus hirsutus extract inhibits the Xanthomonas oryzae pv. oryzae, the bacterial leaf blight pathogen in rice. Arch. Phytopathol. Pl. Protect. 46(15): 1885-1894.

Singh, G., Joyce, E. M., Beddow, J. and Mason, T. J., 2012. Evaluation of antibacterial activity of $\mathrm{ZnO}$ nanoparticles coated sonochemically onto textile fabrics. JMBFS. 2 (1): 106120.

Singh, I., Jaryal, S. C., Thakur, K., Sood, A., Grover, P. S. and Bareja, R., 2015. Isolation and characterization of various Pseudomonas species from distinct clinical specimens. IOSR-JDMS. 14 (6): 80-84.

Trivedi, M. K., Branton, A., Trivedi, D., Nayak, G., Gangwar, M. and Jana, S., 2015. Bacterial identification using $16 \mathrm{~S}$ rDNA gene sequencing and antibiogram analysis on biofield treated Pseudomonas fluorescens. Clin. Med. Biochem. 1:19-25.

\section{How to cite this article:}

Vinay, J.U., V.B. Nargund, S. Jahagirdhar, R.R. Patil and Hegde, R.V. 2018. Green Synthesis of Zinc Nanoparticles using Pseudomonas fluorescens Extract and Their Antibacterial Activity against Xanthomonas spp. Int.J.Curr.Microbiol.App.Sci. 7(10): 1280-1291. doi: https://doi.org/10.20546/ijcmas.2018.710.144 